\title{
Alif Baa Taa Unishams-Style Research
}

\section{Nur Sarah Tajul Urus}

To Link this Article: http://dx.doi.org/10.6007/IJARBSS/v11-i12/11917

DOI:10.6007/IJARBSS/v11-i12/11917

Received: 09 October 2021, Revised: 11 November 2021, Accepted: 27 November 2021

Published Online: 17 December 2021

In-Text Citation: (Urus, 2021)

To Cite this Article: Urus, N. S. T. (2021). Alif Baa Taa Unishams-Style Research. International Journal of Academic Research in Business and Social Sciences, 11(12), 1934-1950.

\section{Copyright: () 2021 The Author(s)}

Published by Human Resource Management Academic Research Society (www.hrmars.com)

This article is published under the Creative Commons Attribution (CC BY 4.0) license. Anyone may reproduce, distribute, translate and create derivative works of this article (for both commercial and non0-commercial purposes), subject to full attribution to the original publication and authors. The full terms of this license may be seen

at: http://creativecommons.org/licences/by/4.0/legalcode

Vol. 11, No. 12, 2021, Pg. $1934-1950$

http://hrmars.com/index.php/pages/detail/IJARBSS

JOURNAL HOMEPAGE

Full Terms \& Conditions of access and use can be found at http://hrmars.com/index.php/pages/detail/publication-ethics 


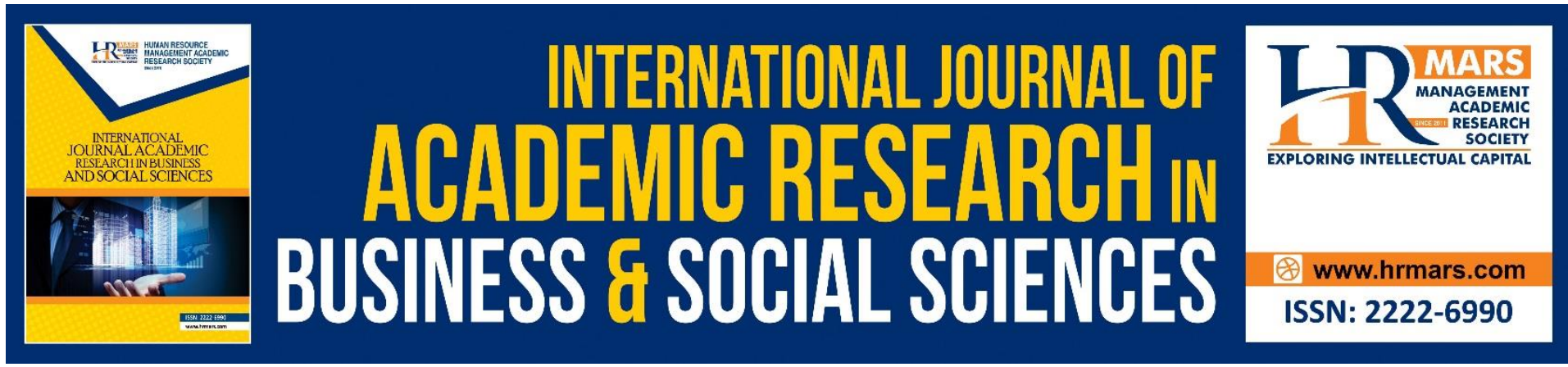

\title{
Alif Baa Taa Unishams-Style Research
}

\author{
Nur Sarah Tajul Urus \\ Lecturer, Kulliyyah of Shariah and Laws, UniSHAMS. \\ Email: nursarah@unishams.edu.my
}

\begin{abstract}
A young author who has only recently entered the field of research should "feel meaningless his spirit" if he lacks a substantial accumulation of intellect and art. This paper will define authentic groundwork, examine current research at UniSHAMS, and propose a broad elemental research structure for an amateur who is 'thirsty for authentic expertise and impressive craft' when planning a research adventure within a timeframe set by an academy or educational institution. This work employs the qualitative mechanism alone through expressive and comparable examination of papers. As a result, the UniSHAMS genre foundation must have assertive personalities in the system to achieve universal requirements and character, so that the blossoming of UniSHAMS performances is assured of quality and has its own and brilliant outlook to be perceived and uplifted to the most immense standard. The magical blow of a coach or supervisor who is enthusiastic about coaching and experiencing information is essential as a mentor for brand-new writers to embark on an academic adventure as a light of more inspired and passionate daring.
\end{abstract}

Keywords: Basic Research Principle, UniSHAMS Style.

\section{Introduction}

An inexperienced author should "feel losing his soul" if he does not have a steady supply of insight and know-how. This paper will investigate what absolute research determines, examine current research at UniSHAMS, and develop an extensive elemental research structure for an apprentice who is 'thirsty for meticulous grasp'.

\section{Research Methodology}

This article employs a completely qualitative approach. Most library-sourced products that are based on published materials, such as textbooks, journal articles, online databases, and the Internet, employ content analysis modes as well. The study employs a unique style of data analysis, namely a descriptive, critical, and comparative approach (Ahmad \& Jamalullail, 2017).

\section{The Beginnings of Research}

The goal of the research is to seek the truth. Islam, as a fantastic way of life, will not allow merely the research component to seek the truth without any instructions and direction. Accept revelation's charters in this situation, such as Surah Sad (38):29, Surah Ra'd (13):3, and 
Surah al-Jathiyyah (45):13. All of these verses instruct people to apply their thoughts and observe the standards for insights presented in order to find assurance in life.

The main question is how Muslims should do research in many fields of knowledge. At the same time, everyone, including religions, nations, cultures, and civilizations, has a unique natural look. Tasawur, as defined by Mohd Syukri Hanapi in Wan Norhaniza (2014), is a response, description, perspective, or point of view on anything. This indicates that a race's or an individual's perspectives on a subject differ from one another, particularly when it comes to abstract conceptions.

The perspective of Islamic nature is critical for coordinating all research operations so that academics do not stray out of sharia orbit. Muslim academics will be able to create a culture of elevated thinking based on the tawhid ideal, which harmoniously unifies all of humanity's knowledge.

The science of techniques or disciplines that investigate processes or ways of understanding things is referred to as methodology. Epistemology is a set of skills that discuss the nature, source, and faith of intelligence. Many scholars are unaware of the epistemology that is being pursued in Islamic studies. The majority of research in the social sciences and humanities uses a research approach based on Western epistemology. The religious study employs a turath technique acknowledged by muktabar academics. Its study techniques vary depending on the discipline, such as Al-Quran studies or Hadith studies.

The West has determined that a field of knowledge must endorse a scientific method based on their epistemological framework. Common research methodologies are flawed and have a number of drawbacks, Muslim scholars argue. Many Muslim thinkers have urged scientists to reconsider the definition of knowledge. Safi (1998) is one of those who actively raise the issue. The others are (Ragab, 2006; Salleh, 2008; Alias, 2015; Miswan, 2013; Hassan, 2013; Firdaus, 2014).

The majority of Muslim scholars' research pursuits are unrelated to the tawhid paradigm or a coherent ideology. There is no simple answer to the state issue. The problem will not be remedied if Muslims continue to employ the Western research framework, particularly at the higher education level.

To that aim, the purpose of this paper is to make numerous ideas for the development of Islamic research methodologies for all fields of knowledge. This writing also intends to guarantee that Muslim researchers focus on developing research methodologies that correctly conform to the Islamic world's vision in order to rebuild the corpus of new knowledge that is more in accordance with the needs and realities of Muslims in particular and humanity in general.

Surah Al-'Alaq:

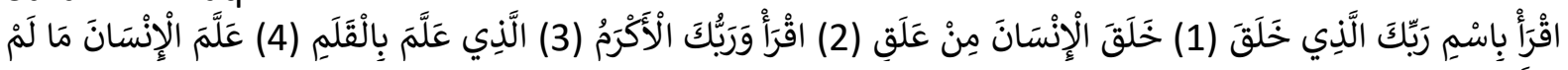

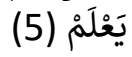


Recite the Name of your Lord who created it. He created a man from a clot. Read, and your Lord is the Most Generous, who teaches (men) by mediation. Taught the man what he did not know.

These magnificent and lovely phrases are the revelation of the First of the Revelations. These words represent the beginning of Allah's kindness, revealed out of love for His followers, and are the benefit that God originally bestowed upon them. This message provides a warning that motivates humans to return to the source of human creation, 'alaqah. And Allah's kindness is that He taught mankind what he does not know. This signifies that God values and respects those who have knowledge.

And wisdom is a treasure peak of knowledge that marks Abul Basyar (Adam) and the angels. Knowledge is sometimes held in the heart, sometimes in the mouth, and sometimes in handwriting. That is, knowledge has three components: knowledge in the heart, spoken knowledge, and written knowledge. Whereas the writing demonstrates competence in both other areas, the reverse is not true.

That is why it is mentioned in his words:

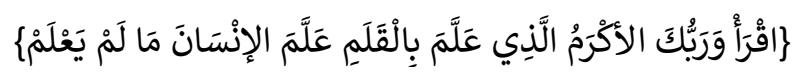

Recite the Name of your Lord who created it. He created a man from a clot. Read, and your Lord is the Most Generous, who teaches (men) by mediation. Taught the man what he did not know (Surah Al-'Alaq: 3-5).

"Tie knowledge with writing," it is mentioned in an athar. And it is still said in the athar that whoever practices what he understands, Allah will offer him wisdom that he does not already have.

According to Syeikh Muhammad 'Abduh, the ability to read quickly and precisely cannot be gained without reciting or disciplining himself on a regular basis, yet such training did not occur in the Prophet Muhammad PBUH. He also revealed two methods in which Allah SWT has arrived to instruct humans. The first is through pen (writing), which must be read by a man, and the second is by direct instruction without the need for instruments. This second method is known as 'ilm Ladunniy.'

Nun did more than simply scrape the curve and point on Buya Hamka. He stated that Nun was the name of the whale that devoured Prophet Yunus when he fled his home nation of Ninawa. The term al-Qalam is also referenced in another verse of Allah.

\section{Surah Lukman 27:}

"And if the trees of the earth were to be pens and the seas were inked, seven more seas would have been added after they had dried up, and the words of Allah would never be exhausted. Verily, All-Mighty, All-Wise."

The interpretation of 'Wal-Qalam' (for the sake of words) in Tafsir Ibnu Katsir by birth means "for the sake of pen". God swears by the pen. The tool used to write. As Allah said in Surah Al-Alaq verse 4, "He who teaches with the pen". 
Furthermore, Al-Qalam denotes pen in Tafsir Al-Misbah. Computers, gadget laptops, and cutting-edge tablets are examples of stationery. Some think that Al-Qalam refers to a certain pen. Like the pen used by angels to write on man's good and terrible fate. In Lauh Mahfuz, the registry of all occurrences is documented. The companions wrote the Qur'an using a pen. Pens are used to record both positive and negative activities performed by people (Shihab, 2002). Understand it more precisely in general. Because of the resemblance to the reading command (Iqra). The first five verses of Surah Al-'Alaq are revealed. What a spirit of literacy, the movement to read and write that is written in the Qur'an. To seek, discover, and share His Most Extensive knowledge with a pen is clear confirmation that reading and writing come from God's commands (writing).

Imam Shafie mentioned six important aspects of studying. This is due to the fact that gaining knowledge has no time restriction. All of these parts must coexist until the knowledge process is complete. Imam Shafie established six requirements for studying:

1. Zaka' - cognitive and intellectual ability. A person who wants to learn must have a sound and prosperous mentality.

2. Hirs - excitement, encouragement, and tenacity.

3. ljtihad - the ability to persevere.

4. Bulqoh - affordability (financial).

5. Irsyad Ustaz - educator guidance.

6. Thuuli Zaman - at all times.

\section{Research Is an ijtihad}

Research is the process of uncovering honesty (ijtihad) and thereby attaining knowledge (Ross, 1974). In Islam, knowledge is valued. Research from an Islamic viewpoint, as one of the subsidiaries in the process of generating knowledge, should also learn from the subjects stressed in the Quran and hadith. As he emphasizes, the most fundamental role of knowledge in Islam is to bring scientists closer to Allah SWT. "... In fact, those who fear Allah among His servants are only knowledgeable". (Surah Fāțir, 35:28).

According to Qutb (2000), Allah SWT elevates the hierarchies of real specialists above those who are ignorant of piety or dread and terror of Allah SWT. A scholar is after the angels, as stated in Surah li 'Imran (3:18): "Allah makes it evident that there is no deity except He who controls (all the worlds) with justice, and the angels and the intelligent..."

According to Qutb (2006), Allah SWT emphasized that the witness He took confirming His oneness came through successive scholars following testimony from angels with the goal of glorifying the group. As stated by the Prophet PBUH, "Indeed, scientists are the descendants of the prophets..." (Narrated by Ab Dawud, hadith no. 3157).

According to the Quran and hadith, scientists are human beings who are exalted by Allah SWT and the Prophet PBUH and get constant benefits from Allah SWT. Although there are verses of the Quran and hadith that express the benefits of experts, or in the context of this article, Muslim researchers who are committed to the truth, there are also hadith that state that this group is one of three groups of people who are thrown into hell on the day of retribution (the other two are martyrs and the most charitable). 
The famous hadith is the Prophet PBUH's statement, which means:

"...A person will come to study, teach, and recite the Qur'an, and he will be shown happiness until he understands it completely, and Allah will ask, 'What have you done?' 'I have learned and imparted knowledge, and I also recite the Quran because of You,' he said. 'You lied, you sought knowledge, taught it, and recited the Qur'an, so that a knowing person is called Qari, and now you are termed like it,' he continued. Then it was ordered that he should be sent into hell..."

(Muslim Narrated Book, no. hadith: 3257).

According to the hadith, even if the group's outward intention is to seek knowledge and impart it, they are not admitted to paradise because they have another goal, which is to obtain a name. In other words, these individuals have a riya' character due to their intents, which are only known to Allah SWT as His statement, which means: "... He is aware of what they conceal and reveal. He is, indeed, the All-Knowing of what is going on inside the chests." (Surah Hūd, 11:5).

The phrase "chest" (as-sudur) is used in the context of this text, yet the heart (al-qalb) is placed in the core of the chest. Al-Fuad is the heart's eye that sees or tastes wisdom (alma'rifat) and secrets (al-asrar) in the center point of al-qalb (Syamsuddin, 2009). These are parts of a conversation on intent. Sincerity is necessary for the context of study so that researchers are directed by Allah SWT since direction from Allah SWT is an indicator of the benefits of the study (Ismail, 2015).

A researcher, as a servant of Allah SWT, must always be honest in his habitual worship, in this case in regard to his research subjects. This is consistent with Allah SWT's statement: "whereas they are not ordered save to worship Allah by doing His worship to Him, and stand strong on the tawhid, and that they establish prayer and pay zakat, and that is the genuine religion" (Surah al-Bayyinah, 98:5). The Surah al-Bayyinah (98:5) verse is a suggestion from Allah SWT to His people who believe to complete all of their worship genuinely exclusively for Him.

Hence, according to Baba (2012), there are four key criteria for assessing if an act is a worship: intention, objectives, method, and aftermath. In the framework of general worship, which is worship other than compulsory or Sunnah worship, the technique is characterized by five primary criteria. First and foremost, the purpose should be only for Allah SWT's sake. Second, what is being done does not violate Islamic Shari'a. Third, the activities should be conducted in conformity with Islamic beliefs. Fourth, the outcome is not Shari'a-compliant. Fifth, traditional worship is not abandoned (Salleh, 2003; Omar, 1999).

As a result, doing research that achieves the measure of worship in Islam should begin with a pure intention (niyyah khalisah). The last step in the goal of doing Islamic research does not cease after the study is completed; rather, it continues after the research is completed. This refers to the level of Allah SWT's reaction to a certain activity. Every human being is responsible for all he does in this setting (al-Ghazali, 1957). As a result, every action is rewarded with sin and reward. However, the decision of sin and reward happens earlier in the process of formulating intentions. 
The Prophet PBUH asserted: "Whoever desires to do good but does not do it, Allah SWT gives him a flawless return for kindness, and if he does good, Allah SWT repays him up to 700 times. Whoever desires to commit evil but does not do it receives a flawless recompense from Allah SWT. If somebody does a bad act, Allah SWT will punish him with a sin of evil." (An-Nawawi, 1988).

A researcher cannot avoid committing crimes by disputing, presenting information, and forming conclusions. When researchers have noble intentions, Allah SWT rewards them for their excellent acts. Islamic scholars pay special attention to errors made in reaching conclusions after putting in a lot of effort into research.

This is explained by a hadith reported to the Prophet PBUH, which states:

"When a judge punishes a matter, it is giving ljtihad and truth, for him two bonuses; when he punishes one item, it is giving and confusion, for him one reward" (narrated by al-Bukhari, no. hadith: 6805). In interpreting the hadith, az-Zuhayli (1986) stated another hadith that permits ijtihad to be formed after studying the Quran's dalil, hadith evidence, and, finally, ijtihad based on thought. (ijtihad bi-ra'y).

Allah SWT will reward the results obtained under the condition of good intentions at the outset of the investigation, sincerity, and total attention. In any case, it is important to underline the importance of a researcher's high degree of dedication in order to achieve the purposes described in the hadith in connection to study.

\section{Alif Baa Taa Unishams-Style Research Concept}

The phrase Alif Baa Taa is defined as a Jawi script or hijaiyyah alphabet that may be used as the foundation or start of research. UniSHAMS style can refer to the mirroring, dancing, arc, or technical framework of research at UniSHAMS. Each institution, of course, has its own style and personality. Why is this style so prominent?

It is none other than to exude the individuality of an IPT, which when breathed is fragrant, when seen is finely carved art in his work, and when heard is excellent and becomes the mouthpiece of society.

The issue that arises in the context of the research adaptation is what sort of information does a researcher need to acquire before doing research? This study tries to answer this topic by arguing that pre-knowledge or previous knowledge is manners. This is demonstrated by the words of the ancient Muslim scholar Ibn al-Mubarak. According to him: "I studied manners for 30 years and academics for 20 years. Let them acquire manners first, and then study ", as reported by Al-Jazar (2006). Ibn al-Mubarak uses the passage to emphasize the significance of understanding and applying etiquette before acquiring sciences in other subjects.

So, what is the significance of manners? According to al-Attas (1980), manners are defined as "recognition and recognition of the fact that knowledge and existence are structured in a dignified manner according to various grades and degrees of their own, and a desirable place for a person in relation to such fact, and the loading and physical, intellectual, and spiritual potential of a person." Manners, in essence, are something that shields humans from making 
poor decisions. In other words, according to al-Attas (1980), wisdom or intelligence in identifying knowledge is a vital factor. In Islam, wisdom is a notion that is grounded by Allah SWT.

This may be observed in Surah al-Baqarah (2:269), which says:

"Allah bestows intelligence on whom He pleases, and whoever receives it receives tremendous good. And only those who employ their intellect may understand exhortation." Wisdom (ulū al-albāb), according to Malik Ibn Anas RA, is "knowing, pondering, and comprehending the method of life established by Allah SWT and putting it into practice" (alQurtubi, 2006).

Morals such as being admirable (maḥmūdah) and deceptive (madhmūmah) are also dependent on degrees in Islamic figh or al-ahkam al-khamsah which is compulsory, circumcised, should, makruh, and haram. This decision is based on the revelation of the Quran and hadith of the Prophet PBUH (Din, 1990; Wahab \& Azmi, 2013). Thus, manners as a whole can develop the conduct and thoughtfulness of a researcher who follows the Quran and hadith's mold (Suhid, 2009).

Needs in the context of research should be driven by feelings of love or passion for carrying out the study. In investigations, needs-based on feelings of love were proven to activate intuition. Al-Ghazali, according to Langgulung (1986), issued directions to stimulate intuition, namely that researchers should not be removed from concentration or study subjects. As a result, a researcher must be well-intentioned and passionate about the subject under investigation. The two aspects of the goal connected to the setting of study, knowledge based on manners and love-based needs, lead to a sort of implication in research that is frankness.

According to Sa'id al-Kharraz (1937), a true person is one who does a duty because Allah SWT controls his thoughts, is careful with his intentions, and seeks the aid of Allah SWT in every task. As a result, the noble goal of doing this serious study has long-term ramifications through the advantages generated from research findings. The long-term effect of this is blessings. Blessings are the outcome of anything that is useful and capable of guiding others (Ismail, 2015). Sincerity can ideally lead to a person's achievement in pursuing the objective of achieving truth and justice (Din, 1991; Abdullah, 2000).

Sincerity is significant in the context so that researchers are guided by Allah SWT, since guidance from Allah SWT is a sign of the blessings of the research done (Ismail, 2015). As a servant of Allah SWT, a researcher should always be honest in his general worship, in this instance in regard to his research matters. This is compatible with Allah SWT's statement: "whereas they are not ordered save to worship Allah by doing his worship to Him, and remain steadfast on the tawhid, and also that they establish prayer and pay zakat, and that is the genuine faith" (al-Bayyinah, 98:5).

\section{Alif Baa Taa Research}

Alif Baa Taa represents the principles of research. Postgraduate students, scholars, and industry participants can all do research. Before beginning a study, a researcher must meticulously prepare. Researchers must get acquainted with the research procedures, 
beginning with the selection of fields and titles, supervisors who are well-educated in the area, and institutions that provide the essential fields and resources.

Academic writing is defined as writing that adheres to worldwide standards while still being tailored to a university's own style. The highlight of the work is a key ability for a researcher to identify research gaps so that the chosen field is investigated or current studies are improved.

\section{Research Restructuring}

A great researcher must have a mentality that allows them to manage their time and work system effectively. As a result, in order to meet the deadline, a research project must have a complete framework. Researchers can produce study material manually in Microsoft Word or utilize current software that speeds up authoring and saves time.

In terms of qualitative technique, researchers can utilize Mindjet mind manager applications, Mendeley, atlas. ti, nvivo, and others. Furthermore, quantitative research can benefit from the employment of apps such as SPSS, PLS, ANOVA, and so on. Mixed method research should be able to use both techniques.

\section{Style of Unishams}

UniSHAMS has been elevated to a full university since 2018, and the reputation of an INSANIAH University College is progressively being enhanced to fulfill the research needs of a full university. UniSHAMS is registered as a private company under the Kedah State Secretariat Corporation, making it a totally owned PHEI of the state government.

Every year, research at UniSHAMS satisfies the standards specified by MyRA and SETARA. Lecturers with grades of 45 and above are eligible to contribute scores to the university for academic activities like patent invention, copyright, impactful journals, scholarly books, research funding, graduates completing, and so on.

University research at UniSHAMS is totally performed by PPSP, RMU, PUKAZ, and Kulliyyah in accordance with the university's tagline, 'UniSHAMS: Wadi Kecemerlangan Ummah,' without relinquishing its goal, 'Exploration Towards Wisdom.'

UniSHAMS researchers are dedicated and doing ongoing research (istiqomah), either as individuals or as part of research groups. Furthermore, always be courteous to God, your parents, instructors, yourself, your spouse, your children, your family, and your friends. The key to success must be emphasized: self-discipline (indibat) and persistent prayers.

\section{Islamic Research Model in General}

Attempts to develop new research concepts that are consistent with the Islamic worldview are not novel. This Islamic study technique has been defined by a number of academics. Among them is Anwar (1994), who characterized Islamic research methodologies as a study that finds answers to questions and problems based on the Quran, al-Sunah, and ijtihad, the three fundamental sources in Islam. 
Islamic research, according to Faridi (1994), is scientific research based on the Quran and Sunnah. He went on to say that Islamic-based research methodologies should have four characteristics: gain information, seek the truth, know Allah SWT, and introduce human values (morals).

In Islam, the goal of inquiry is to discover the truth or facts about anything. The truth is not simply a scientific reality, but it is also a basic truth led by Allah (Rafiuddin, 1999). The truth has four essential elements: truth, wisdom, beauty, and principles of usefulness. These four aspects must be viewed with respect to the principle of tawhid. All four parts must be viewed in a unified manner and complement one another.

Islamic research methodologies hold that the truth is objective, universal, and relevant to all humanity. This is because the truth is all drawn from the Almighty God, both ontologically and epistemologically. Thus, research techniques in Islam can systematically incorporate all sources of information, whether they be sense, intellect, intuition, inspiration, or revelation. Even by understanding this truth, Muslim scholars have a more open path and space in the field of study.

Islam definitely acknowledges scientific study that integrates facts discovered via common sense (logic) and senses (empirically) and even requires that both be used maximally. At the same time, Muslim scholars must see the source of revelations as casting. Muslim researchers were also given the option of using inspiring or intuitive materials in their research or not. It should be underlined, however, that no research in Islam can ever contradict the principles of revelation that have shown to be long-lasting. Thus, in terms of research technique, Islam allows all approaches and methods as long as they do not harm the earth or human life and do not contravene the laws and constraints established by the Quran and Sunnah.

Furthermore, the methodologies and methods adopted must relate to the topic of knowledge to be researched, and they must all be within the context of the Islamic worldview. Failure to comply with this will result in research efforts being conducted outside of the context of worship.

Islamic study has a moral dimension based on religion. This means that research will not be value-free, but rather a method that prioritizes moral ideals in its ontological and epistemological assumptions. Not being free of values here does not imply being nonobjective and biased, but the logic of human reasoning and experience should always be led by the principle of revelation that comes from the Almighty (Bakar, 1991).

The idea of Integrated Islamic Research is an attempt to find the solution and truth to a topic using systematic, trustworthy, and acceptable techniques and based on valid evidence either empirical (experience), logical (aqliyah argument), or naqliyah argument that is within the context of adhering to the Islamic tasawwur or Islamic nature perspective. The outcomes should not be in opposition with the standards of revelation, both good and negative, and should bring mankind closer to God.

The goal of Integrated Islamic Research is to seek the truth in a hierarchical manner. The study in the discipline of revelation science is to discover normative norms in Islam. The goal of 
natural science study is to comprehend nature's or sunnatullah's norms and apply them to universal human existence.

\section{Islamic Research Integrative Approach}

The Concept of Integrated Islamic Research approach according to the Department of Human Sciences (JSK), Universiti Malaysia Kelantan (UMK), As a result of the resolution of the 2017 Tokoh Discourse program, the Department of Human Sciences (JSK), School of Language and Soft Development Universiti Malaysia Kelantan PBI, UMK has taken the initiative to hold a series of serious discussions and a conference in 2018.

A conceptual proposal for integrated Islamic research has been developed as a result of the efforts performed. This endeavour is not yet complete, and it need further feedback and improvements to improve. According to JSK, integrated Islamic research is a way of seeking the truth by acknowledging all sources of knowledge acknowledged in Islamic traditions in a hierarchy and integrating naqli and aqli resources by making the rules of revelation as core and casting. All of these activities are carried out in accordance with the Islamic tasawwur framework in order to seek Allah's favour and benefit Muslims in particular as well as humanity in general.

Islamic-based research adopts the redesigned scientific notion of objective research (based on demonstrating, submitting, and courtesy of the truth of the topic of study), rather than tyranny and placing everything in its proper place. The notion of objectivity held does not deprive researchers of their values, but rather preserves religious convictions and conceptions of truth, honesty, and strong life standards. The purpose of integrated Islamic research is to discover the truth, hold true to it, and propagate it in order to create a new corpus of knowledge based on tawhid principles.

Some conditions must be satisfied in order for research to conform with the Islamic viewpoint, and the first criterion is that the researcher has qualifications with the purpose of satisfying some of the following criteria: i. Firm religious conviction ii. Eligibility to act (mukallaf) iii. Fair and moral with Islamic principles iv. Capable of undertaking research If the prerequisites are not satisfied, Islamic-based research cannot be conducted.

To execute the notion of integrated Islamic research from the standpoint of JSK UMK, research is separated into three components: study design, study methodology (data collection and analysis), and discussion of findings and research formulations. Discussions will be held based on the procedures and components of a research project.

The issue of research in integrated Islamic research should be approached from an Islamic point of view. The solution should benefit both Muslims and humankind as a whole. Problems that are not incompatible with Islam will continue to exist; those that contravene Islamic beliefs must be addressed as soon as possible. The three most important components are the study design, the identification of study problems, and the scope of the research.

In this context, researchers are encouraged to carry out the al-taswir procedure. Al-taswir is the process of gaining an overall picture of a topic by gathering data on issues and difficulties that will be examined. This process consists of eight steps: al-dabit al-ma'lumati (information 
gathering), su'al ahl al-takhsis (expert interview), al-dabit al-tahlili (analysis), al-dabit almakan wa al-zaman (place and time), al-itlaq 'ala 'awamil taghyir al-ahkam (examining the factors that change a ruling), (Abd al-Latif al-Bana, 2010).

The significance of Muslim scholars who have a clear Islamic tasawwur and examine hypotheses within the context of the Islamic worldview. Muslim academics should construct their own theoretical framework based on the study of literature (turath) or adapt current models or theories to mirror or conform to the Islamic viewpoint.

Researchers are urged to conduct a comprehensive and critical review of all past literature or related research based on Islamic views of nature. Integrated Islamic research methodology uses the Rabbani principle (divinity) in the face of the question of nature (natural science) and human sciences.

Islam teaches that God is the 'Ruler and Administrator of nature' and not the law of active causes by itself (self-activating) and is absolutely separate from the power of God and sees it as sunnatullah. This principle recognizes God's power as Rabbul 'Alamin in understanding scientific principles (Abdullah, 2005).

The term 'whole reality' is used in integrated Islamic study. Any study technique and design that is compatible with Islamic epistemology can be used by researchers. There is no question about which technique is the finest or most Islamic as long as they all fit within the framework of the Islamic worldview.

Each field of knowledge has its own research methods. The habits and forms of research in the field of social sciences are not the same as natural sciences. Each requires a methodology that is appropriate to their individual needs. However, the overlap of methods can occur between various disciplines.

Some social sciences and humanities have their own research methods which some also apply scientific research even though not categorically. Generally, natural science and applied sciences use a lot of scientific research involving logical thinking and empirical observations in laboratories to form an understanding of the world around us.

All research whether in the field of Islamic studies, social sciences, natural sciences, or applied science is integrated with Islamic research if it complies with all the conditions stated. Integrating Islamic research that is multidisciplinary, interdisciplinary, or transdisciplinary to be very important and significant.

In integrated Islamic research, primary data is superior to secondary data. The pretext of naqli is preferred over the dalil aqli. The most fundamental thing throughout the data collection process is that the conduct or morals of researchers must be in line with the teachings of Islam.

An important aspect that should be taken into account by researchers in the process of gathering information in integrated Islamic research is to use the right language and take into 
account the quality of the respondent (meet face to face, have witnesses, be fair), writes Nafis al-Hussein.

Researchers were urged to pre-analyze (textual analysis and content analysis) and accept a diversity of data output forms (dabit sadri and kitabi) as well as in modern form. Data collection methods must also be in line with the objectives and requirements of the study.

Data analysis from the perspective of integrated Islamic research is divided into three parts. Data analysis in the field of syariah memorized apply the process of al-hukm i.e., data using Usul al-Fiqh method such as istinbati, istiqra'i, istirdadi and jadali.

The broad inductive (istiqra'), deductive (istinbat), and comparative procedures are commonly utilized to assess turath specialization data. Some scholars use critical analytical methods on data gathered, such as the tahqiq approach of books or antique manuscripts. Quantitative data analysis Integrated Islamic Research receives data in quantitative form. The application of algebra and statistical mathematics is a data analysis tool that has been validated in integrated Islamic research. Statistics are classified into two types: descriptive statistics (such as mode, median, mean, standard deviation, and so on) and inference statistics (such as t-tests, khi-squared tests, colleration, regression, ANOVA, MANOVA and MANCOVA).

The hypothesis based on the theoretical framework/conceptual framework based on the Islamic nature perspective must be tested by scientific investigation with its new meaning. It is possible to accomplish this by following the instructions below: $i$. Hypothesis test the hypothesis developed from an integrated theoretical framework should be examined in a "whole reality" by recognising the link between physical and metaphysical features. ii. If the notion of an integrated theoretical framework is accepted, it signifies that trust in the theoretical framework grows and becomes a valid fact. iii. If the hypothesis is rejected, it signifies that the knowledge or interpretation of the theoretical framework is incorrect and needs to be revised, or the research techniques and processes need to be reviewed and improved. iv. There is no conflict between revelation and common sense. Both are from Allah, and there is no conflict between them.

Qualitative data from observation records, interviews, or documents are also collected for integrated Islamic research. All qualitative data must be evaluated narratively. Unpublished papers such as court case reports, police records, meeting minutes, and the like provide qualitative data from the source of the documents in question here. Thus, data that are Quranic texts, hadith or turath books, or datasecunder sources (theses, books, journals, and the like highlighted in literary studies) are separated from the context of qualitative analysis. The process of analyzing qualitative data begins with observing, organizing, filtering, choosing, categorizing, and encoding themes, followed by category selection (Miswan, 2013).

\section{Findings}

UniSHAMS-style research must have certain characteristics in order to achieve standards and quality to Allah SWT. The production of UniSHAMS works is guaranteed of quality and has its own and bright future. A magical touch from a mentor or supervisor is essential as a guide for young writers. 
The PPSP has published thesis handbook and is limited to writing format only. This handbook is not enough for young researchers looking to start research at UniSHAMS. External examiners of thesis especially in the aspects of academic writing style, standard methodology, etc. need to be analyzed and made recommendations for improvements. Meanwhile, RMU has the capacity to manage external and internal university funds such as PUKAZ, MyRA, and SETARA.

\section{Discussions and Conclusion}

The findings of this study can serve as a guideline and reference to assist UniSHAMS in improving the quality of research handling more efficiently and professionally. The basis of the research is a very important component and must be well mastered before starting a research, according to the researchers.

This study may explain young researchers' confusion about the important foundations in the world of research. Based on this understanding, the university community's negative perception of the research and publication processes that have to go through lengthy procedures, can be changed and thus improve the excellence of its implementation.

This article has fulfilled and aligned with the theme of UniSHAMS Research Cluster Serial Webinar 2021, "Blessings of Research in Intellectual Culture". It is hoped that the results and recommendations in this article will be useful in the importance of the policy to all young researchers.

\section{Recommendation and Suggestions}

1. UniSHAMS should give a research manual to researchers as a complete resource.

2. The existing thesis format manual should be revised in accordance with current demands and the context of the Ministry of Higher Education.

3. The Library must improve its skills, particularly in the area of digitalization of information channels, and provide important international reference facilities such as the journal link Scopus and others.

4. It is recommended that research on social sciences in Islamic studies include elements of fiqhiyyah and maqasid syariah methods in the context of the submission of research writing consisting of theses, journal articles, books, or academic articles in the mainstream media, either through electronic channels or printing. It has the potential to strengthen the current Islamic worldview, as evidenced by the evidence in the first and second sources of Islamic submissions. Meanwhile, Islamic law and law might incorporate such aspects as well as draw parallels with civil and international law. All of them are designed to deliver a more universal and universal touch while also achieving higher quality.

5. The academic writing and technique styles employed in the Kulliyyah of Syariah and Law, UniSHAMS are viewed as distinct from the mainstream, with lecturers themselves having two versions, Malaysian and Middle Eastern. This has to be adjusted so that only one standard format is utilized.

6. Primary sources are field studies discovered by scholars. While secondary sources are divided into two categories, the first is the classic source of revelation (referring to the knowledge of revelation and the turath book), and the second is the standard library resource. 
7. The integrated Islamic research plans offered are far from flawless. This paper attempts to lay out the fundamental principles that every researcher who wishes to apply an integrated Islamic research idea must follow. It is hoped that this writing will be updated and will encourage other parties to build a higher-quality Islamic research model in the future.

8. Improve research at UniSHAMS by upgrading RMU to RMC.

a) To submit research grant reports in the form of book designs for the benefit of the UniSHAMS community and surrounding communities.

b) An easy-to-use e-book that can be referred to on a worldwide platform.

c) To create a large number of master and doctoral graduates.

d) Campaigns to raise awareness among students who work as research assistants on research grants.

e) Include a post-doctoral fellowship and a visiting professorship.

f) Include a day off and leave in the industrial field.

g) Promote lecturers by increasing quotas for senior lecturers, associate professors, and professors.

h) Instill inspiration and motivation in students and lecturers about the satisfaction of research so that new knowledge can be explored and shared with the community through the publication of articles in journals, books, and presentations at academic conferences, as well as knowledge sharing in the community field.

i) To establish a network of academic partnerships with RMC IPTs both locally and internationally.

\section{Acknowledgment}

This research received specific funding for ERA publication from UniSHAMS Research Cluster Serial Webinar 2021: 1 st and 2nd Series, on 22nd September and 13th October 2021 at UniSHAMS, Kuala Ketil, Baling, Kedah, Darul Aman, Malaysia.

\section{Corresponding Author}

Nur Sarah binti Tajul Urus

Lecturer, Kulliyyah of Syariah and Law, Universiti Islam Antarabangsa Sultan Abdul Halim Mu'adzam Shah (UniSHAMS), Malaysia.

Email: nursarah@unishams.edu.my

\section{References}

Setia, A. (2010). Kesalingkaitan antara agama dan sains : ke arah meletakkan semula sains dan teknologi di bawah pengarahan shariah Islamiah. Dalam Islam dan sains dalam pembangunan tamadun. Penyusun. Azizan Baharuddin dan Shamsuddin Moner. Kuala Lumpur : Universiti Malaya

Abdullah, A. R. H. (2005). Wacana falsafah ilmu. Kuala Lumpur: Utusan Publications \& Distributors Sdn. Bhd.

Ismail, A. M., \& Ali, M. N. S. (2016). Kaedah penyelidikan sosial daripada perspektif Islam. Bangi : Penerbit UKM

Long, A. S. (2015). Metodologi penyelidikan pengajian Islam. Bangi : Penerbit UKM

Ghazali, A., \& Sarani, A. S. (2014). Manual penyelidikan secara Islam. Selangor : Institut Perkembangan Minda (INMIND) 
Faridi, F. A. (1994). Islamic research methodology; some reflection. DIm. Mohammad Muslim (ed), Research Methodology In Islamic Perspective. New Delhi: Institute of Objective Studies.Hamid Fahmy Zarkasyi. (2012). Misykat; refleksi tentang westernisasi, liberalisasi dan Islam. Jakarta: INSISTS

Zarkasyi, H. F. (2005). Worldview sebagai asas epistemology Islam. Islamia, Vol IINo35.April 920. 96

Ibrahim, A. R. (2006). The methodology of Islamizing human science. DIm. Mohd Yusof Hussain (pnyt.) (2006). Islamization of human sciences. Kuala Lumpur: Research Centre IIUM.

Ibrahim, A. R. (1995). On the nature and scope of the Islamization process; toward conceptual clarification. Intellectual Discourse, 3(2) : 113-122.

Ibrahim, A. R. (1998). On the methodology of Islamization of the social sciences. Kertas Kerja International Conference of Sociology and Anthropology. International Islamic University Malaysia, Kuala Lumpur.

Louay, S. (1998). Asas ilmu pengetahuan : satu kajian perbandingan kaedah-kaedah penyelidikan Islam dan Barat. Terj. Nur Hadi Ihsan. Selangor : Thinker's Library Sdn. Bhd.

Miswan, M. S. M. (2013). Aplikasi Dilalat dalam kaedah penyelidikan berteraskan Islam. Kertas kerja dalam International Islamic Development Management Conference (IDMAC), Universiti Sains Malaysia, 9-10 Disember 2013.

Alias, M. S. (2015). Ibn al-Haytham; pelopor konsep penyelidikan saintifik. Kuala Lumpur: Dewan Bahasa dan Pustaka.

Hanapi, M. S. (2014). Tasawur pembangunan berteraskan Islam. DIm. Wan Norhaniza Wan Hasan. (pnyt.). Ukuran pembangunan; pendekatan kapitalis dan Islami., hlm. 59-85. Kuala Lumpur: Dewan Bahasa dan Pustaka.

Anwar, M. (1994). Research methodology in Islamic perspective. Dlm. Mohammad Muslim (ed), Research Methodology In Islamic Perspective. New Delhi: Institute of Objective Studies.

MuslimK, M. (pet.). 1999. Research methodology in Islamic perspective. Kuala Lumpur: Synergy Book International

Rafiuddin, M. (1999). The meaning and purpose of Islamic research. Dlm. Mohammad Muslim (ed), Research Methodology In Islamic Perspective. New Delhi: Institute of Objective Studies.

Ali, M. M. (ed) (1996). Conceptual and Methodological Issues in Islamic Research: A Few Milestones. Kuala Lumpur: Dewan Bahasa dan Pustaka (DBP).

Ali, M. M. (2008). Islamic critique of conventional research methodologies. Kertas kerja dalam Wacana Penyelidikan ISDEV. Universiti Sains Malaysia, 12 Disember 2007.

Saleh, M. S. (2008). Kaedah penyelidikan berteraskan Islam; keperluan, kedudukan dan halatuju. Dlm. Pemikir 54, hIm. 133-164, Oktober-Disember 2008.

Saleh, M. S. (2011). Ke arah pembinaan kaedah penyelidikan berteraskan Islam. DIm. Zakaria Bahari, Fadzila Azni Ahmad dan Roselee Shah Shararudin (ed). 2011. Pengurusan ilmu, ekonomi dan pembangunan berteraskan Islam. Pulau Pinang : Penerbit Universiti Sains Malaysia. .

Bakar, O. (1991). Tawhid and science: essays on the history and philosophy of Islamic science. Pulau Pinang: Secretariat for Islamic Philosophy and Science.

Hassan, S. A. (2013). Penerapan kaedah pengumpulan hadith dalam penyelidikan.Kuala Lumpur : Dewan Bahasa dan Pustaka. 
Khairuldin, W. M. K. F. W. (2014). Aplikasi proses penfatwaan dalam kaedah penyelidikan berteraskan Islam. Tesis Doktor Falsafah. Universiti Sains Malaysia

Hisham, N. B. (2019). Kaedah Penyelidikan Islam Bersepadu: Pencarian Kebenaran Dan Keberkatan IImu. Journal of Islamic, Social, Economics and Development (JISED), 4(19), 84-96. 